\title{
LEMBAGA PENJAMIN SIMPANAN DALAM LIKUIDASI BANK DI INDONESIA
}

\author{
Hendri Jayadi \\ Jimmy Simanjuntak \\ hendrijayadi79@gmail.com \\ Universitas Kristen Indonesia, Jakarta, Indonesia
}

\begin{abstract}
Legally, LPS has been regulated in Law Number 24 of 2004 concerning the Deposit Insurance Corporation. LPS itself has two functions, namely guaranteeing bank customer deposits and resolving failed bank disputes through liquidation. The process of bank liquidation carried out by the Indonesia Deposit Insurance Corporation through the Liquidation Team of the bank is never complete or leaves a problem for bank customers whose savings are not guaranteed by the Deposit Insurance Corporation. The existence of the Deposit Insurance Agency is also expected to be able to carry out its functions properly in guaranteeing limited bank customer deposits so as to support efforts in stability in the banking sector.
\end{abstract}

Keyword : customer bank; guaranteed; depositsl; LPS.

\section{Pendahuluan}

Industri perbankan merupakan salah satu komponen penting dalam perekonomian nasional demi menjaga keseimbangan kemajuan dan kesatuan ekonomi nasional. Stabilitas industri perbankan dimaksud sangat mempengaruhi stabilitas perekonomian secara keseluruhan.

Kepercayaan masyarakat terhadap industri perbankan nasional merupakan salah satu kunci untuk memelihara stabilitas industri perbankan sehingga krisis tersebut tidak terulang. Kepercayaan ini dapat diperoleh dengan adanya kepastian hukum dalam pengaturan dan pengawasan bank serta penjaminan simpanan nasabah bank untuk meningkatkan kelangsungan usaha bank secara sehat. Kelangsungan usaha bank secara sehat dapat menjamin keamanan simpanan para nasabahnya serta meningkatkan peran bank sebagai penyedia dana pembangunan dan pelayan jasa perbankan.

Krisis moneter yang menghantam Indonesia pada tahun 1998 ditandai dengan dilikuidasinya 16 bank, hal ini mengakibatkan menurunnya tingkat kepercayaan masyarakat pada sistem perbankan. Untuk mengatasi krisis moneter dan kepercayaan masyarakat, pemerintah mengeluarkan beberapa kebijakan, di antaranya memberikan jaminan atas seluruh kewajiban pembayaran bank, termasuk simpanan masyarakat (blanket guarantee). 1 Dalam pelaksanaannya, blanket guarante memiliki ruang lingkup penjaminan yang terlalu luas sehingga menyebabkan timbulnya moral hazard baik dari sisi pengelola bank maupun masyarakat. Untuk mengatasi hal tersebut, program penjaminan yang cakupannya terlalu luas diganti dengan sistem penjaminan yang terbatas.

Sistem penjaminan terbatas diimplementasikan melalui pembentukan Lembaga Penjamin Simpanan sebagai pelaksana penjaminan dana masyarakat. Lembaga Penjamin Simpanan dibentuk berdasarkan Undang-undang Nomor 24 Tahun 2004. Secara yuridis, LPS telah diatur di dalam Undang-Undang Nomor 24 tahun 2004 tentang Lembaga Penjamin Simpanan. LPS sendiri memiliki dua fungsi yaitu menjamin simpanan nasabah bank dan melakukan penyelesaian sengketa bank gagal melalui likuidasi.

$\overline{1 \mathrm{http} ; / / \mathrm{www} . l p s . g o . i d}$, sejarah pendirian, diakses pada tanggal, 10, September, 2019. 
Likuidasi adalah pencabutan izin usaha bank yang meliputi pembubaran badan hukum bank dan proses penyelesaian terhadap seluruh hak dan kewajiban bank.2

Berdasarkan ketentuan Pasal 37 ayat (3) dan (4) UU Perbankan disebutkan bahwa suatu bank dapat dicabut ijin usahanya oleh menteri dalam hal ini adalah Menteri Keuangan Republik Indonesia berdasarkan usulan dari Bank Indonesia, kemudian memerintahkan agar proses likuidasi terhadap bank tersebut segera dilaksanakan. Pengertian likuidasi bank berdasarkan ketentuan Pasal 17 ayat (1) Peraturan Pemerintah No. 68 Tahun 1996 tentang Ketentuan dan Tata Cara Pencabutan Izin Usaha, Pembubaran dan Likuidasi Bank, yaitu tindakan pemberesan berupa penyelesaian seluruh hak dan kewajiban bank sebagai akibat pembubaran badan hukum bank.

Bank dapat dicabut ijin usahanya dan mengalami likuidasi apabila memenuhi syarat-syarat sebagaimana diatur dalam penjelasan Pasal 2 ayat (1) Peraturan Pemerintah No. 68 Tahun 1996 tentang Ketentuan dan Tata Cara Pencabutan Izin Usaha, Pembubaran dan Likuidasi Bank. Bank dalam likuidasi adalah suatu bank dalam keadaan mengalami kesulitan yang membahayakan kelangsungan usahanya apabila berdasarkan penelitian Bank Indonesia, bank berada dalam kondisi usaha yang semakin memburuk hal mana ditandai dengan :

- Menurunnya permodalan;

- Menurunnya kualitas asset;

- Menurunnya rentabilitas;

- Menurunnya likuiditas;

- Pengelolaan bank tidak dilakukan berdasarkan prinsip kehati-hatian dan azas perbankan yang sehat.

Proses penutupan suatu bank belum diketahui apakah ketika Bank Indonesia memutuskan untuk mencabut ijin usaha bank kemudian melikuidasi suatu bank, Bank Indonesia telah menyiapkan langkahlangkah strategis untuk menyelesaikan permasalahan yang muncul, khususnya mengenai pengembalian simpanan dana para nasabah bank pada bank dalam likuidasi tersebut. Persoalan lain akan muncul kembali terkait aset-aset yang dimiliki oleh Bank dalam

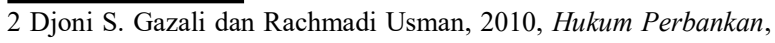
Sinar Grafika, Jakarta, h. 532 likuidasi tersebut jumlahnya atau nilainya lebih kecil daripada simpanan dana para nasabah bank tersebut. Permasalahan lain akan muncul terkait kredit-kredit yang pernah diberikan oleh bank dalam likuidasi tersebut kepada nasabah yang memiliki kredit pada bank dalam likuidasi tersebut, pihak mana dan berkenaan dengan cara pengelolaannya. Masalah ini yang kerap kali muncul dalam hal terjadinya likuidasi terhadap bank sampai dengan saat ini, selain itu bagi nasabah-nasabah yang nilai simpanannya melebihi batas yang dijamin oleh pemerintah melalui Lembaga Penjamin Simpanan. Nomenklatur dalam Lembaga Penjamin Simpanan untuk nasabah yang tidak dijamin disebut nasabah yang memiliki simpanan yang "tidak wajar". Permasalahan istilah "tidak wajar" tersebut menimbulkan akibat banyak nasabah-nasabah mengajukan gugatan terhadap Lembaga Penjamin Simpanan.

\section{Pembahasan}

\section{Lembaga Penjamin Simpanan dalam Likui- dasi Bank di Indonesia}

Lembaga Penjamin Simpanan didirikan dengan maksud sebagaimana dalam pertimbangan UndangUndang Nomor 24 tahun 2004 tentang Lembaga Penjamin Simpanan yaitu:

- Untuk menunjang terwujudnya perekonomian nasional yang stabil dan tangguh, diperlukan suatu sistem perbankan yang sehat dan stabil.

- Untuk mendukung sistem perbankan yang sehat dan stabil diperlukan penyempurnaan terhadap program penjaminan simpanan nasabah bank.

- Melaksanakan program penjaminan terhadap simpanan nasabah bank tersebut perlu dibentuk suatu lembaga yang independen yang diberi tugas dan wewenang untuk melaksanakan program dimaksud diatas.

Pembentukan Lembaga Penjamin Simpanan dengan maksud dan tujuan sebagaimana dimaksud diatas sehingga, dalam memutuskan dan melaksanakan likuidasi terhadap suatu bank harus dipertimbangkan dengan pertimbangan yang sangat matang dan perhitungan yang komprehensif. Proses likuidasi bank yang di lakukan oleh Lembaga Penjamin Simpanan melalui Tim Likuidasi terhadap bank tidak 
pernah tuntas atau menyisakan masalah bagi nasabah bank yang simpananya tidak dijamin oleh Lembaga Penjamin Simpanan. Tim Likuidasi dalam hal ini dituntut kinerja dan profesionalisme untuk melakukan proses likuidasi bank yang berkeadilan, karena dalam teori keadilan pancasila sebagaimana diuraikan tujuan dibuatnya suatu peraturan hukum untuk mewujudkan sila ke lima keadilan sosial bagi seluruh rakyat Indonesia dengan menjunjung tinggi asas kepastian hukum dan kemanfaatan hukum.

Pertanggungjawaban Lembaga Penjamin Simpanan terhadap simpanan nasabah apabila suatu bank terlikuidasi, maka Lembaga Penjamin Simpanan akan membayar sejumlah simpanan nasabah yang ada di dalam bank tersebut paling tinggi $\mathrm{Rp}$. 2.000.000.000,-(Dua miliar rupiah) dengan bunga dibawah $7 \%$ pada setiap nasabah per-bank dengan memperhatikan beberapa hal-hal, sebagai berikut:

1. Lembaga Penjamin Simpanan melakukan rekonsiliasi dan verifikasi simpanan yang dijamin terhadap data nasabah penyimpan berdasarkan data bank per tanggal pencabutan izin usaha untuk menentukan:
a. Simpanan yang layak dibayar; dan
b. Simpanan yang tidak layak dibayar.

2. Lembaga Penjamin Simpanan dapat menunjuk, menguasakan, dan/atau menugaskan pihak lain untuk melakukan rekonsiliasi dan verifikasi bagi kepentingan dan/atau atas nama Lembaga Penjamin Simpanan.

3. Rekonsiliasi dan verifikasi dilakukan secara bertahap berdasarkan rekening yang lebih mudah diverifikasi.

4. Penentuan Simpanan yang layak bayar berdasarkan hasil rekonsiliasi dan verifikasi diselesaikan paling lambat 90 (sembilan puluh) hari kerja terhitung sejak izin usaha bank dicabut.

Lembaga Penjamin Simpanan dalam rangka kegiatan rekonsiliasi dan verifikasi simpanan yang dijamin terhadap data nasabah penyimpan, pegawai bank, direksi, komisaris, dan pemegang saham, yang dicabut izin usahanya wajib membantu memberikan segala data dan informasi yang diperlukan, yaitu:

Daftar simpanan nasabah yang tercatat dalam pembukuan bank;

- Daftar simpanan nasabah yang juga memiliki kewajiban kepada bank yang telah jatuh tempo dan/atau gagal bayar;

- Daftar tagihan bank kepada nasabah debitur, termasuk yang telah dihapusbukukan oleh bank;

- Standar Operating Procedure (SOP) internal bank yang berkenaan dengan simpanan nasabah;

- Susunan Direksi, Komisaris, dan Pemegang Saham bank;

- Neraca dan rinciannya dan;

- Data dan dokumen pendukung lain yang diperlu-kan Lembaga Penjamin Simpanan.

Penjabaran lebih lanjut mengenai likuidasi bank diatur dalam Peraturan Lembaga Penjamin Simpanan Nomor 01/PLPS Tahun 2011 Tentang likuidasi bank, mengemukakan yang di maksud dengan Bank Gagal (Failing Bank) yaitu: Bank yang mengalami kesulitan keuangan dan membahayakan kelangsungan usahanya serta dinyatakan tidak dapat lagi disehatkan oleh lembaga pengawas perbankan sesuai dengan kewenangan yang dimiliki. Lembaga Penjamin Simpanan oleh karena itu sesuai dengan kewenangan yang dimiliki, apabila suatu bank sudah dinyatakan sebagai Bank Gagal, bank tersebut di likuidasi.

Peraturan Lembaga Penjamin Simpanan (PLPS Nomor 1 Tahun 2011) tentang likuidasi bank menjelaskan likuidasi bank merupakan tindakan penyelesaian seluruh aset dan kewajiban bank sebagai akibat pencabutan izin usaha dan pembubaran badan hukum bank.3 Bank yang mengalami masalah, pilihan untuk menutup adalah pilihan terakhir, karena baik pemilik dan nasabah yang terkait dengan bank tindakan pembubaran (likuidasi). Konsekuensi yuridis dicabutnya izin usaha bank maka eksistensi bank sebagai badan usaha berakhir pula. Secara yuridis bank tersebut tidak dimungkinkan hidup kembali.4

Ketentuan hukum tentang likuidasi terhadap bank di Indonesia dilakukan dengan dalam tatanan sistem tertentu, sehingga pelaksanaan likuidasi tersebut dapat dilakukan secara efisien dan efektif serta dilakukan

3 Sentosa Sembiring., Hukum Perbankan, Bandung: Mandar Maju, Edisi Revisi, 2012, hlm. 257.

4 Andrian Sutedi, Hukum Perbankan Suatu Tinjauan Pencucian Uang, Merger, Likuidasi, dan Kepailitan, Jakarta: Sinar Grafika, 2007, hlm. 159 
dalam waktu singkat dan kepercayaan terhadap bank, akibat adanya likuidasi memberikan akibat negatif khususnya terhadap tingkat kepercayaan masyarakat terhadap bank, dan juga nasabah penabung dan deposan dari bank yang dilikuidasi.s

Lembaga Penjamin Simpanan segera melakukan tindakan yang diperlukan dalam rangka pengamanan aset bank sebelum proses likuidasi dimulai, yaitu:

- Menguasai dan mengelola aset bank.

- Mengelola kewajiban bank.

- Berkoordinasi dengan Bank Indonesia, Lembaga Pengawas Perbankan, kepolisian dan instansi terkait lainnya.

\section{Permasalahan Lembaga Penjamin Simpanan dalam Likuidasi Bank}

Lembaga Penjamin Simpanan dalam rangka melaksanakan tugasnya sebagaimana dimaksud dalam Pasal 5 Undang-Undang Nomor 24 Tahun 2004 tetang Lembaga Penjamin Simpanan, mempunyai wewenang yaitu menetapkan dan memungut premi penjaminan serta menetapkan dan memungut kontribusi pada saat bank pertama kali menjadi peserta. Bank yang melakukan kegiatan usaha di wilayah Republik Indonesia wajib menjadi peserta penjaminan Lembaga Penjamin Simpanan. Kontribusi kepesertaan bagi bank-bank yang menjadi peserta Lembaga Penjamin Simpanan ini diatur lebih lanjut dalam ketentuan Pasal 12 dan pasal 13 Undang-Undang Nomor 24 Tahun 2004 tentang Lembaga Penjamin Simpanan.

Premi Penjaminan sebagaimana dimaksud dalam Pasal 9 huruf c dibayarkan 2 (dua) kali dalam 1 (satu) tahun untuk:

- Pembayaran periode 1 Januari sampai dengan 30 Juni; dan

- Pembayaran periode 1 Juli sampai dengan 31 Desember.

- Premi untuk masing-masing periode sebagaimana dimaksud pada ayat dibayarkan selambat-lambatnya tanggal:

- 31 Januari untuk periode sebagaimana dimaksud pada ayat (1) huruf a; dan

5 I Gusti Agung Bagus Hendra Praditya, dkk, Akibat Hukum Likuidasi Bank Terhadap Keberadaan Akta Pemberian Hak Tanggungan, 2017- 2018. Jurnal Ilmiah Prodi Magister Kenotariatan, hlm 197.
- 31 Juli untuk periode sebagaimana dimaksud pada ayat (1) huruf b; berdasarkan rata-rata saldo bulanan total Simpanan pada periode sebelumnya.

Premi sebagaimana dimaksud pada ayat (2) ditambah atau dikurangi sesuai dengan realisasi ratarata saldo bulanan total Simpanan pada periode yang bersangkutan. Penambahan atau pengurangan premi sebagaimana dimaksud pada ayat (3) dilakukan pada saat pembayaran premi untuk periode berikutnya.

Ketentuan lebih lanjut mengenai tata cara pembayaran premi ditetapkan dengan Peraturan Lembaga Penjamin Simpanan.

Pasal 13 Undang-Undang Nomor 24 Tahun 2004 tentang Lembaga Penjamin Simpanan menyebutkan:

- Premi untuk setiap periode sebagaimana dimaksud dalam Pasal 12 ditetapkan sama untuk setiap bank sebesar $0,1 \%$ (satu perseribu) dari rata-rata saldo bulanan total simpanan dalam setiap periode.

- Tingkat premi sebagaimana dimaksud pada ayat (1) dapat diubah apabila dipenuhi sekurangkurangnya satu kriteria berikut:

- Terjadi perubahan nilai simpanan yang dijamin untuk setiap nasabah pada satu bank sebagaimana dimaksud dalam Pasal 11 ayat (1);

- Akumulasi cadangan penjaminan telah melampaui tingkat sasaran sebesar 2,5\% (dua puluh lima perseribu) dari total Simpanan di setiap bank; atau

- Terjadi perubahan tingkat risiko kegagalan (exposure) pada industri perbankan.

Perubahan tingkat premi sebagaimana dimaksud pada ayat (2) dikonsultasikan dengan Dewan Perwakilan Rakyat. Hasil konsultasi sebagaimana dimaksud pada ayat (3) ditetapkan lebih lanjut dengan Peraturan Pemerintah.

Setiap bank yang telah menjadi peserta Lembaga Penjamin Simpanan diwajibkan untuk membayar premi penjaminan kepada Lembaga Penjamin Simpanan. Besarnya premi penjaminan yang harus dibayar oleh bank peserta tersebut ditetapkan oleh Lembaga Penjamin Simpanan. Kewenangan yang dimiliki oleh Lembaga Penjamin Simpanan tidak terlepas dari fungsi yang melekat padanya, sebagai penjamin simpanan nasabah bank dan juga sebagai pemelihara stabilitas sistem perbankan. Lazimnya 
suatu lembaga penjamin simpanan yang dibentuk di negara-negara lain, Lembaga Penjamin Simpanan juga diharapkan dapat menjalankan fungsinya dengan baik dalam menjamin simpanan nasabah bank secara terbatas sehingga mendukung upaya stabilitas sektor perbankan. Pada saat bersamaan, Lembaga Penjamin Simpanan juga diharapkan dapat menangani permasalahan yang dialami oleh bank peserta program penjaminan. Fungsi ini dilengkapi kewenangan untuk menangani penutupan bank bermasalah hingga pelaksanaan likuidasinya, semangat dari kelaziman fungsi ini adalah karena sebagai lembaga yang menjamin simpanan nasabah, Lembaga Penjamin Simpanan memiliki exposure risiko terbesar apabila bank pesertanya ditutup.

Istilah premi yang digunakan dalam pembayaran keanggotaan Lembaga Penjamin Simpanan artinya mengadopsi prinsip asuransi dimana pembayaran premi tersebut dihitung dari rata-rata saldo bulanan total simpanan dalam setiap periode di kalikan 0, 1\% dan dibayarkan dua kali dalam satu tahun, akan tetapi yang dibayarkan sebagai nasabah bank yang dijamin oleh Lembaga Penjamin Simpanan hanya nasabah yang memiliki simpanan kurang dari Rp. 2.000.000.000,-(Dua miliar Rupiah) dengan bunga dibawah $7 \%$ (tujuh persen). Lembaga Penjamin Simpanan dalam hal ini sangat kontradiksi dan sangat merugikan nasabah penyimpan dana di bank khususnya bagi nasabah yang memiliki dana diatas jumlah yang dijamin, seharusnya perlindungan hukum yang diberikan oleh pemerintah adalah menggunakan prinsip asuransi dengan membayarkan seluruh klaim dari nasabah penyimpan dana tanpa melihat jumlah maksimum yang dijamin. Ketentuan Pasal Pasal 54 ayat (5) Undang-Undang Nomor 24 Tahun 2004 Tentang Lembaga Penjamin Simpanan mengatur apabila seluruh aset bank telah habis dalam proses likuidasi dan masih terdapat kewajiban bank terhadap pihak lain maka kewajiban tersebut wajib dibayarkan oleh pemegang saham lama yang terbukti menyebabkan bank menjadi gagal.

Berdasarkan ketentuan tersebut sebagai wujud nyata perlindungan hukum yang diberikan oleh pemerintah kepada nasabah penyimpan dana bank khususnya nasabah yang simpananya tidak "dijamin" oleh Lembaga Penjamin Simpanan biasanya dibayarkan terakhir dari sisa hasil likuidasi. Pada umumnya sisa hasil likuidasi tersebut tidak mencukupi mengembalikan dana nasabah oleh karenanya dengan mempertimbangkan ketentuan hukum diatas maka pemerintah dalam hal ini Lembaga Penjamin Simpanan dan Lembaga Pemerintah lainnya yang mengurusi permasalahan perbankan dapat mengakomodir kepentingan para nasabah tersebut dengan membuka akses seluas-luasnya berkaitan dengan susunan pemegang saham bank dalam likuidasi, memberikan informasi yang selengkap-lengkapnya dengan bukti-bukti hukum yang membuktikan bahwa pemegang saham tersebut yang mengakibatkan bank menjadi gagal. Pemerintah bila perlu membuat lembaga yang mewakili nasabah untuk menggugat pemegang saham lama yang mengakibatkan Bank Gagal.

Berdasarkan ketentuan Pasal 54 ayat 1 UndangUndang Nomor 24 Tahun 2004 tentang Lembaga Penjamin Simpanan merupakan hirarki dalam likuidasi bank. Memprioritaskan dana talangan yang dibayarkan dari aset bank hal ini sangat merugikan nasabah karena timbul pertanyaan kemana premi yang dibayarkan oleh bank-bank yang menjadi anggota Lembaga Penjamin Simpanan, jika dilihat dari jumlah premi yang dibayarkan sangat besar.

\section{Kesimpulan dan Saran}

Lembaga Penjamin Simpanan pada dasarnya bertujuan untuk melindungi dana nasabah pada saat bank dilikuidasi. Dengan adanya lembaga yang menjamin simpanan maka akan memberikan rasa aman bagi masyarakat yang menyimpan dananya di bank meskipun bank tersebut mengalami kegagalan. Hal ini dapat menumbuhkan kembali kepercayaan masyarakat terhadap industri perbankan nasional yang belakangan ini melemah karena dengan adanya penjaminan tersebut masyarakat nasabah dapat dengan tenang menyimpan dananya di bank.

Adanya Lembaga Penjamin Simpanan tidak menutup kemungkinan terjadinya moral hazard. Untuk itu LPS berkoordinasi dengan Bank Indonesia beserta pemerintah harus memperketat pengawasan dan pengaturan terhadap industri perbankan nasional dalam menjalankan kegiatan usahanya agar tidak terjadi lagi krisis perbankan. 


\section{Daftar Pustaka}

Djoni S. Gazali dan Rachmadi Usman, Hukum Perbankan, Sinar Grafika, Jakarta. 2010.

Sentosa Sembiring., Hukum Perbankan, Bandung: Mandar Maju, Edisi Revisi, 2012.

Andrian Sutedi, Hukum Perbankan Suatu Tinjauan Pencucian Uang, Merger, Likuidasi, dan Kepaili-tan, Jakarta: Sinar Grafika, 2007.

I Gusti Agung Bagus Hendra Praditya, dkk, Akibat Hukum Likuidasi Bank Terhadap Keberadaan Akta Pemberian Hak Tanggungan, 2017- 2018. Jurnal Ilmiah Prodi Magister Kenotariatan.

\section{Internet}

http;//www.lps.go.id, sejarah pendirian, diakses pada tanggal, 10, September, 2019.

\section{Peraturan Perundan-Undangan}

Undang-undang UU No. 10 Tahun 1998 Tentang Perubahan Atas UU No. 7 Tahun 1992 Tentang Perbankan.

Undang-Undang Nomor 24 Tahun 2004 tentang Lem-baga Penjamin Simpanan.

Peraturan Lembaga Penjamin Simpanan Nomor 01/ PLPS Tahun 2011 Tentang likuidasi bank.

Peraturan Pemerintah No. 68 Tahun 1996 tentang Ketentuan dan Tata Cara Pencabutan Izin Usaha, Pembubaran dan Likuidasi Bank. 